\title{
Urine Catalytic Iron and Neutrophil Gelatinase-Associated Lipocalin as Companion Early Markers of Acute Kidney Injury after Cardiac Surgery: A Prospective Pilot Study
}

\author{
Krittapoom Akrawinthawong ${ }^{a} \quad$ Michael K. Shaw ${ }^{b}$ Joshua Kachner ${ }^{\text {a }}$ \\ Eugene O. Apostolov ${ }^{c}$ Alexie G. Basnakiand ${ }^{d}$ Sudhir Shah $^{\mathrm{e}}$ \\ Jacqueline Tilak ${ }^{f, g}$ Peter A. McCullough ${ }^{f, g}$ \\ a Department of Internal Medicine, St. John Hospital and Medical Center, Detroit, Mich., \\ bSt. John Macomb-Oakland Center, Warren, Mich., 'Department of Pharmacology and \\ Toxicology, and Department of Nephrology, Internal Medicine, University of Arkansas \\ for Medical Sciences, ${ }^{d}$ DNA Damage and Toxicology Core Center, and Department of \\ Pharmacology and Toxicology, University of Arkansas for Medical Sciences, and e Division \\ of Nephrology, Department of Medicine, Central Arkansas Veterans Healthcare System and \\ University of Arkansas for Medical Sciences, Little Rock, Ariz., and ${ }^{\mathrm{f} P r o v i d e n c e ~ H o s p i t a l s}$ \\ and Medical Centers, Southfield, Mich. and Novi, Mich., and ${ }^{9}$ St. John Providence Health \\ System, Warren, Mich., USA
}

\section{Key Words}

Catalytic iron - Marker - Neutrophil gelatinase-associated lipocalin · Acute kidney injury · Heart surgery

\begin{abstract}
Background: Open heart surgery with cardiopulmonary bypass is recognized as a common cause of acute kidney injury (AKI). The conventional biomarker creatinine is not sensitive enough to detect AKI until a significant decline in renal filtration has occurred. Urine neutrophil gelatinase-associated lipocalin (NGAL), part of an acute response to the release of tissue iron from cells, is an early biomarker and a predictor of AKI in a variety of clinical settings. We sought to evaluate the relationship between urine catalytic iron (unbound iron) and NGAL over the course of AKI due to cardiac surgery. Methods: Fourteen patients who underwent open heart surgery had the following measured: serum creatinine $(0,12,24,48$ and $72 \mathrm{~h}$ postoperatively), urine NGAL and urine catalytic iron $(0,8,24$ and $48 \mathrm{~h}$ postoperatively). Urine NGAL and urine catalytic iron were quantified by immunoassay and bleomycin-detectable iron assay, respectively. AKI was defined by the Acute Kidney Injury Network (AKIN) criteria.
\end{abstract}


Results: Urine catalytic iron increased significantly $(p<0.05)$ within $8 \mathrm{~h}$ and peaked at $24 \mathrm{~h}$ postoperatively in patients who developed AKI $(n=8$, baseline $101.96 \pm 177.48$, peak 226.35 $\pm 238.23 \mathrm{nmol} / \mathrm{l}, \mathrm{p}=0.006)$, but not in non-AKI patients $(\mathrm{n}=6$, baseline $131.08 \pm 116.21$, peak $163.99 \pm 109.62 \mathrm{nmol} / \mathrm{l}, \mathrm{p}=0.380$ ). Urine NGAL levels also peaked at $24 \mathrm{~h}$ with significant increase observed only in AKI patients: AKI - baseline $34.88 \pm 26.47$, peak $65.50 \pm 27.03 \mathrm{ng} / \mathrm{ml}$, $p=0.043$; non-AKI - baseline $59.33 \pm 31.72$, peak $71.00 \pm 31.76 \mathrm{ng} / \mathrm{ml}, \mathrm{p}=0.100$. The correlation between baseline levels of urine catalytic iron and NGAL and peak levels of urine catalytic iron and NGAL was $r=0.86, p<0.0001$. Conclusion: Urine catalytic iron appears to rise and fall in concert with NGAL in patients undergoing cardiac surgery and may be indicative of early AKI. Future research into the role that catalytic iron plays in acute organ injury syndromes and its potential diagnostic and therapeutic implications is warranted.

Copyright $@ 2013$ S. Karger AG, Basel

\section{Introduction}

Acute kidney injury (AKI) is a common complication in hospitalized patients and is associated with significant morbidity and mortality including increased length of hospitalization and poor clinical outcomes [1]. Data from a recent multinational multicenter study showed that cardiac surgery with cardiopulmonary bypass (CPB) is the second most common cause of AKI among hospitalized patients [2]. Because the pathophysiology is not well established and there is no effective prophylaxis, early detection may be a cornerstone in dealing with this critical condition over the next several years.

The use of creatinine as a biomarker for AKI is limited in that its level rises after kidney injury has already occurred. Moreover, the creatinine assay across laboratories has not been well standardized. Recently, data showed that $41.1 \%$ of patients with AKI would go undiagnosed by using serum creatinine alone [3]. A novel marker that rises earlier than creatinine could allow for prompt detection and interventions to retard the progression of AKI.

Proteomic analysis has uncovered a number of interesting proteins in plasma and urine responsible for ischemic renal injury [4,5]. Among these, neutrophil gelatinase-associated lipocalin (NGAL) is a promising transport protein that has been vigorously tested in a variety of patient settings as a predictor for AKI and poor clinical outcome [6-8] and also as a detector of AKI up to $48 \mathrm{~h}$ earlier than serum creatinine [9]. Its role as a biomarker still needs more exploration in particular situations, i.e. when the baseline NGAL is elevated and when the results from NGAL and serum creatinine are found to be discordant $[10,11]$.

Interestingly, this $25-\mathrm{kDa}$ lipocalin-2 is known to have a scavenging role for labile ironsiderophore to prevent bacterial growth [12]. This putative mechanism raises the possibility of catalytic iron for use as a biomarker for earlier detection of organ injury. Several models of AKI, i.e. rhabdomyolysis, cisplatin-induced kidney injury, etc. [13], revealed the robust role of catalytic iron in their pathophysiology. Furthermore, Ho et al. [14] recently reported proteomic evidence that hepcidin-25, which is a regulator of iron homeostasis, may be protective in CPB patients and this was confirmed by a study from Haase-Fielitz et al. [15] who investigated urine hepcidin-25 isoforms as an early indicator in those who will not develop AKI. Therefore, urine catalytic iron, which is readily bound by urine NGAL or if unbound is reabsorbed at the level of the thick ascending limb of Henle's loop (TAL) and cortical collecting tubule in human kidney [16], merits study as a marker of AKI.

To our knowledge, there has been no human study regarding the relationship between urine catalytic iron and NGAL measured in the same patients, at the same time in the setting of cardiac surgery. Thus, we report serial values of both measures in a small cohort of unselected individuals undergoing surgery requiring CPB. 


\section{CardioRenal Medicine}

(C) 2013 S. Karger AG, Basel www.karger.com/crm

Akrawinthawong et al.: Urine Catalytic Iron and Neutrophil Gelatinase-Associated Lipocalin as Companion Early Markers of Acute Kidney Injury after Cardiac Surgery

\section{Methods}

\section{Patient Population}

All patients of at least 18 years of age undergoing elective coronary artery bypass grafting surgery and/ or heart valve surgery with planned CPB at Providence Hospitals and Medical Centers were invited for participation in the study. A total of 14 patients enrolled into this pilot study. We excluded patients who had an estimated glomerular filtration rate (GFR) of less than $30 \mathrm{ml} / \mathrm{min} / 1.73 \mathrm{~m}^{2}$, underwent emergency surgery, were being treated for active infection (i.e. sepsis, endocarditis), or developed shock or hemodynamic compromise which required a vasopressor. Renal function was monitored up to $72 \mathrm{~h}$ postoperatively. Informed consent was obtained and this study was conducted in compliance with the Declaration of Helsinki.

\section{Data Collection and Definition}

Demographic and clinical data (table 1) were collected for baseline at the time of admission. Serum creatinine, urine NGAL and catalytic iron were collected for baseline $3 \mathrm{~h}$ before starting surgery.

AKI was defined by Acute Kidney Injury Network (AKIN) criteria: an elevation of serum creatinine of at least $0.3 \mathrm{mg} / \mathrm{dl}$, an increase of $50 \%$ compared to baseline within $48 \mathrm{~h}$ or a reduction in urine output defined as $<0.5 \mathrm{ml} / \mathrm{kg} / \mathrm{h}$ for more than $6 \mathrm{~h}$ after open heart surgery.

\section{Sampling and Biochemical Analysis}

For serum creatinine, blood sampling was done at $12,24,48$ and $72 \mathrm{~h}$ postoperatively due to the schedule of laboratory work. Urine samples $(6 \mathrm{ml})$ were collected in biosampler tubes at 8,24 and $48 \mathrm{~h}$ after open heart surgery and immediately placed on ice. Samples were centrifuged $\left(1,500 \mathrm{rpm}, 15 \mathrm{~min}, 4^{\circ} \mathrm{C}\right)$ to remove any sediment. Patient samples were aliquoted into $3 \mathrm{ml}$ tubes and were frozen at $-70^{\circ} \mathrm{C}$ until used for biomarker analysis.

NGAL levels were measured using a capture/detection enzyme-linked immunosorbent assay per manufacturer's instructions (Kamiya Biomedical, Seattle, Wash., USA) and samples were analyzed in triplicate (Assay Designs Inc.). An interassay and intra-assay coefficient of variation (CV) of less than $10 \%$ was accepted. Serum creatinine levels (mg/dl) were determined by the St. John Providence Health System clinical laboratory using colorimetric assay (Beckman Coulter Inc.). Intra-assay CV was $4.3 \%$. A combined interassay and intra-assay CV of less than $10 \%$ was considered acceptable for results reporting. For CV results above an intra-assay CV of $10 \%$, the test was repeated. Urine catalytic iron was measured by bleomycin-detectable iron assay which uses the principle of deoxyribonucleic acid degradation by bleomycin in the presence of catalytic iron [17]. All reagents were pretreated with chelex using polypropylene tubes in order to avoid external iron contamination. Urine NGAL and catalytic iron excretion were measured in nanograms per milliliters and nanomoles per liter, respectively.

\section{Statistical Analysis}

SPSS version 15.0 (SPSS Inc., Chicago, Ill., USA) was used for all statistical analyses. For non-parametric statistics, the Mann-Whitney U test was used to compare the AKI and non-AKI group for continuous variables, whereas Fisher's exact test was used for categorical variables due to the small number of subjects. Spearman's correlation was applied to correlate between urine catalytic iron and NGAL level. A p value of less than 0.05 was considered as statistical significant. All graphs were constructed by GraphPad Prism ${ }^{\circledR}$ version 5.0. Data are presented as mean \pm SD.

\section{Results}

\section{Patient Characteristics}

Patients' demographics, intra-operative risks of AKI, co-morbidities and operative details are summarized in table 1. Eight of fourteen patients in this study were found to have AKI according to the AKIN criteria. There was no significant difference observed ( $p>0.05)$ between the AKI and non-AKI group except for type of surgery and duration of CPB which were significantly associated with postoperative AKI. 
Table 1. Characteristics and marker levels of patients undergoing open heart surgery compared between the AKI and non-AKI group

\begin{tabular}{|c|c|c|c|c|}
\hline \multirow[t]{2}{*}{ Variables } & \multicolumn{2}{|c|}{ All patients $(n=14)$} & \multirow[t]{2}{*}{ Total } & \multirow[t]{2}{*}{$\mathrm{p}$ value } \\
\hline & $\mathrm{AKI}(\mathrm{n}=8)$ & non-AKI $(n=6)$ & & \\
\hline \multicolumn{5}{|l|}{ Patient characteristics } \\
\hline Age, years & $74.63 \pm 10.90$ & $62.33 \pm 11.96$ & $69.36 \pm 12.60$ & 0.081 \\
\hline Race $^{1}$ (African/White), n & $4 / 4$ & $3 / 3$ & 12 & 0.704 \\
\hline Sex (female/male), n & $4 / 4$ & $4 / 2$ & 12 & 0.627 \\
\hline \multicolumn{5}{|l|}{ Underlying disease } \\
\hline Hypertension, $\mathrm{n}$ & 8 & 4 & 12 & 0.165 \\
\hline Dyslipidemia, $\mathrm{n}$ & 5 & 3 & 8 & 0.521 \\
\hline Diabetes, $\mathrm{n}$ & 3 & 3 & 6 & 0.529 \\
\hline History of $\mathrm{CKD}^{2}, \mathrm{n}$ & 4 & 0 & 4 & 0.085 \\
\hline History of smoking, $\mathrm{n}$ & 3 & 3 & 6 & 0.529 \\
\hline \multicolumn{5}{|l|}{ Details of hospitalization } \\
\hline Baseline hemoglobin ${ }^{3}, \mathrm{~g} / \mathrm{dl}$ & $10.16 \pm 1.39$ & $11.22 \pm 2.04$ & $10.65 \pm 1.74$ & 0.534 \\
\hline Blood transfusion ${ }^{4}$, units & $1.00 \pm 0.00$ & $1.60 \pm 0.89$ & $1.30 \pm 0.67$ & 0.310 \\
\hline Duration of surgery, min & $310.88 \pm 149.76$ & $343.17 \pm 102.72$ & $324.71 \pm 128.10$ & 0.573 \\
\hline Timing of on-pump 5 , min & $121.88 \pm 67.37$ & $25.33 \pm 39.86$ & $80.50 \pm 74.25$ & $0.012^{*}$ \\
\hline Cardiac catheterization ${ }^{6}, \mathrm{~h}$ & $10.50 \pm 19.70$ & $8.00 \pm 19.60$ & $9.43 \pm 18.93$ & 0.852 \\
\hline \multicolumn{5}{|l|}{ Left ventricular ejection fraction } \\
\hline before operation, $\%$ & $46.25 \pm 8.35$ & $45.00 \pm 16.58$ & $45.77 \pm 11.52$ & 0.943 \\
\hline Vasopressor use ${ }^{7}, \mathrm{n}$ & 2 & 2 & 4 & 0.733 \\
\hline Length of stay, days & $12.50 \pm 7.29$ & $8.33 \pm 2.66$ & $10.71 \pm 5.99$ & 0.414 \\
\hline Total dose of diuretics ${ }^{8}, \mathrm{mg}$ & $70.00 \pm 28.28$ & $73.33 \pm 30.11$ & $71.42 \pm 27.97$ & 0.852 \\
\hline Coronary artery bypass graft surgery, $n$ & 7 & 1 & 8 & $0.026^{*}$ \\
\hline Heart valve surgery, $n$ & 1 & 5 & 6 & \\
\hline \multicolumn{5}{|l|}{ Level of markers } \\
\hline \multicolumn{5}{|l|}{ Creatinine, $\mathrm{mg} / \mathrm{dl}$} \\
\hline At baseline $\mathrm{Cr}$ & $1.14 \pm 0.50$ & $1.03 \pm 0.14$ & $1.09 \pm 0.38$ & 0.142 \\
\hline At $12 \mathrm{~h}$ postoperatively & $1.44 \pm 0.41$ & $0.98 \pm 0.24$ & $1.24 \pm 0.41$ & $0.029 *$ \\
\hline At $24 \mathrm{~h}$ postoperatively & $1.63 \pm 0.68$ & $0.95 \pm 0.22$ & $1.33 \pm 0.59$ & $0.008^{*}$ \\
\hline At $48 \mathrm{~h}$ postoperatively & $1.75 \pm 1.06$ & $0.93 \pm 0.19$ & $1.40 \pm 0.89$ & $0.043^{*}$ \\
\hline At $72 \mathrm{~h}$ postoperatively & $1.98 \pm 0.84$ & $0.88 \pm 0.21$ & $1.51 \pm 0.85$ & $0.005^{*}$ \\
\hline \multicolumn{5}{|l|}{$\mathrm{GFR}, \mathrm{ml} / \mathrm{min} / 1.73 \mathrm{~m}^{2}$} \\
\hline $\mathrm{GFR}_{0}$ & $49.25 \pm 31.87$ & $62.09 \pm 33.14$ & $53.32 \pm 35.41$ & $0.037^{*}$ \\
\hline $\mathrm{GFR}_{12}$ & $33.02 \pm 29.58$ & $39.02 \pm 47.82$ & $35.26 \pm 40.01$ & 0.634 \\
\hline $\mathrm{GFR}_{24}$ & $34.27 \pm 23.02$ & $40.68 \pm 46.36$ & $37.13 \pm 35.28$ & 0.847 \\
\hline $\mathrm{GFR}_{48}$ & $32.75 \pm 24.96$ & $41.34 \pm 47.93$ & $35.33 \pm 34.58$ & 0.847 \\
\hline $\mathrm{GFR}_{72}$ & $38.98 \pm 30.06$ & $47.96 \pm 55.80$ & $42.54 \pm 41.57$ & 0.852 \\
\hline \multicolumn{5}{|l|}{ NGAL, ng/ml } \\
\hline At baseline & $34.88 \pm 26.47$ & $59.33 \pm 31.72$ & $45.36 \pm 30.36$ & 0.142 \\
\hline At $8 \mathrm{~h}$ postoperatively & $59.67 \pm 23.14$ & $64.50 \pm 28.18$ & $60.21 \pm 33.28$ & 0.345 \\
\hline At $24 \mathrm{~h}$ postoperatively & $65.50 \pm 27.03$ & $71.00 \pm 31.76$ & $67.86 \pm 28.10$ & 0.950 \\
\hline At $48 \mathrm{~h}$ postoperatively & $44.38 \pm 26.80$ & $50.83 \pm 32.49$ & $47.14 \pm 28.35$ & 0.852 \\
\hline \multicolumn{5}{|l|}{ Catalytic iron, nmol/l } \\
\hline At baseline & $101.96 \pm 177.48$ & $131.08 \pm 116.21$ & $108.05 \pm 152.62$ & 0.573 \\
\hline At $8 \mathrm{~h}$ postoperatively & $159.90 \pm 126.16$ & $121.86 \pm 99.99$ & $135.73 \pm 127.53$ & 0.755 \\
\hline At $24 \mathrm{~h}$ postoperatively & $226.35 \pm 238.23$ & $163.99 \pm 109.62$ & $191.56 \pm 196.53$ & 0.755 \\
\hline At $48 \mathrm{~h}$ postoperatively & $196.66 \pm 181.23$ & $80.41 \pm 87.28$ & $143.16 \pm 158.51$ & 0.081 \\
\hline
\end{tabular}


Akrawinthawong et al.: Urine Catalytic Iron and Neutrophil Gelatinase-Associated Lipocalin as Companion Early Markers of Acute Kidney Injury after Cardiac Surgery

Fig. 1. Time trend for urine catalytic iron and NGAL for all patients $(\mathrm{n}=14)$.

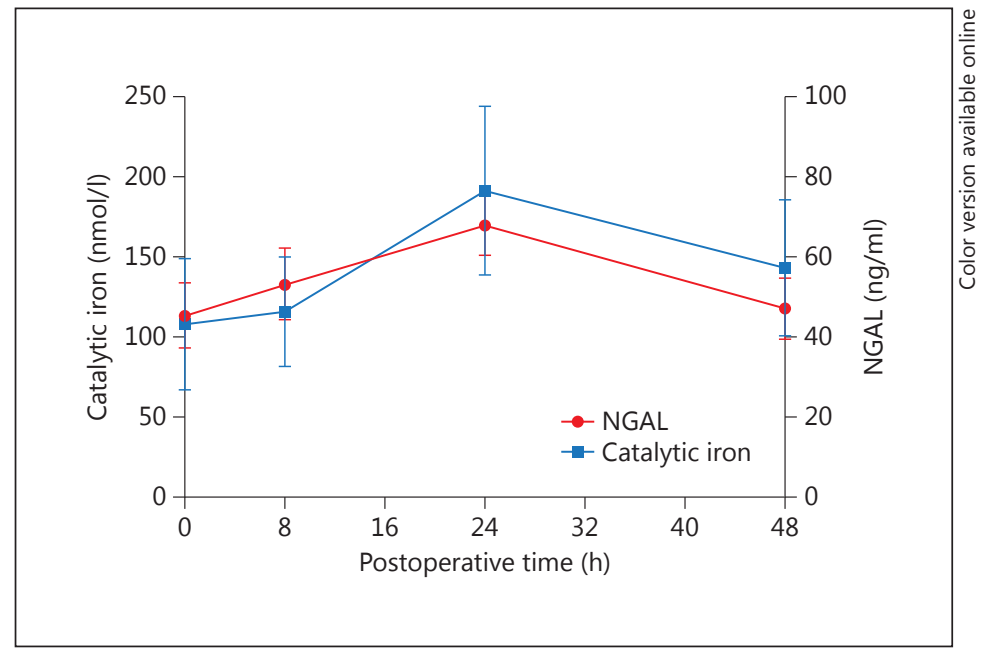

Baseline Levels and Postoperative Changes of Serum Creatinine, Urine Catalytic Iron and

NGAL

Overall excursions for urine catalytic iron and NGAL are shown in figure 1. Urine catalytic iron increased significantly $(\mathrm{p}<0.05)$ within $8 \mathrm{~h}$ and peaked at $24 \mathrm{~h}$ postoperatively in patients who developed AKI ( $\mathrm{n}=8$, baseline $101.96 \pm 177.48$, peak $226.35 \pm 238.23 \mathrm{nmol} / \mathrm{l}, \mathrm{p}=0.006)$, but not in non-AKI patients $(n=6$, baseline $131.08 \pm 116.21$, peak $163.99 \pm 109.62 \mathrm{nmol} / \mathrm{l}$, $\mathrm{p}=0.380$ ). Those changes also remained up to at least $48 \mathrm{~h}$ after surgery (fig. 2 ). Urine NGAL levels also peaked at $24 \mathrm{~h}$ with significant increase observed only in AKI patients: AKI baseline $34.88 \pm 26.47$, peak $65.50 \pm 27.03 \mathrm{ng} / \mathrm{ml}, \mathrm{p}=0.043$; non-AKI - baseline $59.33 \pm 31.72$, peak $71.00 \pm 31.76 \mathrm{ng} / \mathrm{ml}, \mathrm{p}=0.100$. For all three markers, there was no significant difference found between the AKI and non-AKI group at baseline (table 1). For serum creatinine, the AKI group showed significant change compared with the non-AKI group at $12 \mathrm{~h}$ after the operation and this difference persisted at least $72 \mathrm{~h}$ postoperatively.

A total of 10 subjects underwent intra-operative blood transfusion. There were no differences at baseline, peak, or from baseline to peak in catalytic iron, NGAL, or serum creatinine (online suppl. material, see www.karger.com/doi/10.1159/000346815).

(Footnote to table 1.)

Values are given as mean \pm SD, unless indicated otherwise. GFR was calculated by MDRD equation.

$\mathrm{CKD}=$ Chronic kidney disease; $\mathrm{Cr}=$ creatinine.

${ }^{1}$ Race: there are only African-American and Caucasian people in this study.

${ }^{2}$ History of CKD: defined by the National Kidney Foundation (NKF) criteria.

${ }^{3}$ Baseline hemoglobin: value at $24 \mathrm{~h}$ before operation.

${ }^{4}$ Amount of blood transfusions since $24 \mathrm{~h}$ before operation until $48 \mathrm{~h}$ postoperatively ( $1 \mathrm{unit}$ of red blood cells $=350 \mathrm{ml}$ ).

${ }^{5} \mathrm{CPB}$ pump duration: measured in minutes.

${ }^{6}$ Prior diagnostic cardiac catheterization before the operation.

${ }^{7}$ Number of subjects who used vasopressor (dopamine, dobutamine and norepinephrine).

${ }^{8}$ Furosemide treatment within $72 \mathrm{~h}$ after the operation.

* p value $<0.05$, statistically significant. 
CardioRenal

Medicine

Fig. 2. Postoperative change of urine NGAL, urine catalytic iron and serum creatinine according to the development of AKI ${ }^{*} \mathrm{p}<$ 0.05 compared with baseline at time zero).

Fig. 3. Scatter plot of the pairs of 'baseline urine NGAL and baseline urine catalytic iron', also 'peak of urine NGAL and peak of urine catalytic iron' ( $r=0.86, \mathrm{p}<0.0001$; Spearman's correlation). (c) 2013 S. Karger AG, Basel www.karger.com/crm

Akrawinthawong et al.: Urine Catalytic Iron and Neutrophil Gelatinase-Associated Lipocalin as Companion Early Markers of Acute Kidney Injury after Cardiac Surgery
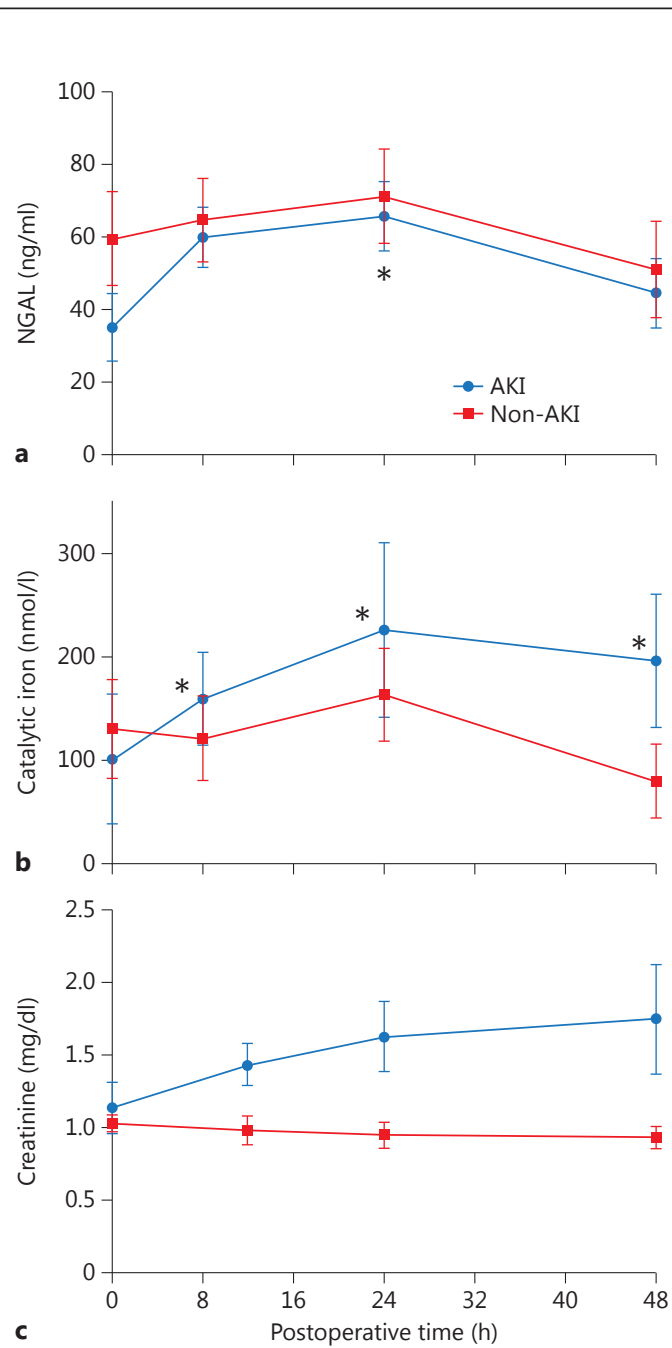

C (1) 


\section{CardioRenal Medicine}

\begin{tabular}{l|l}
\hline Cardiorenal Med 2013;3:7-16 \\
\hline DOI: $10.1159 / 000346815$ & $\begin{array}{l}\text { C 2013 S. Karger AG, Basel } \\
\text { www.karger.com/crm }\end{array}$ \\
\hline
\end{tabular}

Akrawinthawong et al.: Urine Catalytic Iron and Neutrophil Gelatinase-Associated Lipocalin as Companion Early Markers of Acute Kidney Injury after Cardiac Surgery

\section{Correlation of Urine Catalytic Iron and NGAL}

There was a graphical trend of urine catalytic iron and urine NGAL levels observed postoperatively (fig. 1). Using Spearman's correlation with matched data between urine catalytic iron and urine NGAL at both baseline and peak level, a strong correlation was observed between these two biomarkers (fig. $3 ; \mathrm{r}=0.86, \mathrm{p}<0.0001$ ).

\section{Discussion}

In our prospective pilot study, the majority of recruited patients was elderly and had low GFR at baseline. The significant association between coronary artery bypass graft and duration of CPB with AKI was found here as in previous studies $[18,19]$. Serum creatinine measurements showed that AKI persisted at least $72 \mathrm{~h}$ after surgery. As expected, urine catalytic iron in those that developed AKI remained elevated compared to baseline for at least $48 \mathrm{~h}$ postoperatively. The fact that there was no significant difference in urine NGAL and catalytic iron level between the AKI and non-AKI group is consistent with our very small sample size and the large known variation in NGAL levels [20].

In recent years, there has been a growing body of knowledge regarding novel biomarkers for AKI such as NGAL, hepcidin, alpha-1 microglobulin and fatty acid-binding proteins, pointing toward catalytic iron as an important player in the pathophysiology of AKI. NGAL is a wellknown siderophore-binding lipocalin that is released in response to free iron in cytosol or the pericellular spaces of the kidney to promote intracellular iron accumulation [21]. Its role is to prevent intracellular iron depletion which is a mechanism for cellular apoptosis. Hepcidin, which is also expressed in apical tubular epithelium of the TAL and cortical collecting duct [22] and recognized as a central regulator of iron homeostasis [23], was found to be an early predictive marker to rule out AKI in CPB patients [15]. Alpha-1 microglobulin, which is a marker indicating proximal tubular injury, has the role in heme degradation that contributes to toxic renal injury by released free iron $[24,25]$. Fatty acid-binding protein is also a highaffinity heme-binding protein that was found to be increased in relation to the patients who developed AKI after cardiac surgery [26]. Considering all of this supporting evidence, catalytic iron in urine, which is the product of the target organ that we are investigating, is a reasonable promising candidate for early biomarkers of AKI. Interestingly, free iron release is the earliest observed signal for the elevation of other biomarkers associated with AKI. This observation accentuates the rationale of urine catalytic iron being a measurable determinant of AKI.

The pathogenesis of AKI in cardiac surgery with CPB is still a conundrum [2,27]. Poorly liganded iron can be released from the myocardium, rise as a result of hemolysis with $\mathrm{CPB}$, and possibly be locally produced in the kidney as part of the pathophysiology of AKI. Possible explanations of how free iron causes AKI in this context include oxidative stress via the HaberWeiss reaction and hemolysis due to pump use causing depletion of nitric oxide (NO). In patients undergoing $\mathrm{CPB}$, there are elevations of markers of systemic inflammation [28-30] and significant hemolysis $[18,31,32]$. Old-stored red blood cell transfusion also potentially contributes free hemoglobin which has been found to scavenge NO [33]. Since NO is a potent vasodilator, depletion of NO causes vasoconstriction, exacerbating the poor tissue perfusion already present in the transient low-cardiac output state during the transition off the pump [21]. Moreover, heme release increases catalytic iron levels [34]. Those free iron ions catalyze the Haber-Weiss reaction under the acidic milieu caused by tissue hypoxia to generate hydroxyl radicals that injure renal cells. It has been known that a high concentration of ferrous $\left(\mathrm{Fe}^{2+}\right)$ iron exerts a cytotoxic effect, especially in the proximal tubule [35-38]. It stands to reason that decreasing urinary iron excretion could decrease the rate of kidney function deterioration [39, 40]. Those proposed mechanisms may explain a recent study which showed that the volume 
Akrawinthawong et al.: Urine Catalytic Iron and Neutrophil Gelatinase-Associated

of a red blood cell transfusion is independently associated with AKI in patients who underwent CPB-using cardiac surgery [41]. However, such findings were not observed in our study. There was no significant difference in the rise of catalytic iron and NGAL between blood-transfusion and non-blood-transfusion groups. Also, no correlation between the transfused blood volume and peak level of biomarkers was observed (see online suppl. material). Since there is no reported active secretion of free iron from renal tubules, there are three possibilities to explain how catalytic iron leaks into urine. First, there is the overspill mechanism from hemolysis combining with activated heme oxygenase-1, the heme catabolism enzyme, in hypoxic condition [42] overwhelming iron reabsorption at the TAL and collecting ducts [16]. Second, there is decreased reabsorption of iron in the tubules as AKI progresses. Third, there is elevated local release of free iron from mitochondria of damaged renal cells [43] occurring primarily in the proximal tubule and the TAL, where a high number of mitochondria are found [44]. Taken together, the existing evidence regarding the role of catalytic iron in AKI pathogenesis of cardiac surgery with $\mathrm{CPB}$ and iron leakage under such conditions strongly support urine catalytic iron as a potential early biomarker for AKI in open heart surgery patients.

This is the first study investigating urine catalytic iron and urine NGAL simultaneously in open heart surgery patients. Our study displays a correlation between urine catalytic iron and NGAL levels and indicates that monitoring urine catalytic iron serially from baseline to postoperative phase can potentially detect AKI earlier than using the conventional marker serum creatinine or the novel marker urine NGAL. Furthermore, a combination of these markers may allow clinicians to overcome the limits of each marker when used individually and more effectively identify AKI in cardiac surgery patients.

Our study has all the limitations of pilot studies with very small sample sizes. Urine output was not available in the postoperative phase, eliminating its potential use in diagnosing AKI using AKIN criteria; however, Prowle et al. [44] have suggested that only creatinine is often sufficient and thus obviating urine output criteria. Next, the earliest time of measurement of urine catalytic iron and NGAL postoperatively was $8 \mathrm{~h}$, eliminating the possibility of earlier detection of a rise in these biomarkers. Also, our urinary markers were not adjusted for urinary dilution. Lastly, the serum catalytic iron was not measured, which could have been used to correlate with urine catalytic iron levels or to verify the proposed spillover effect of iron potentially released by the heart or from hemolysis as a contributor to AKI [45]. Although catalytic iron seems to be a key player in the common pathway of tissue injury, this finding should not be extrapolated into other clinical contexts associated with AKI due to the unique pathophysiology in each setting.

Our findings show that baseline and postoperative serial urine catalytic iron measurements are valuable indicators of AKI after open heart surgery. Urine catalytic iron levels are highly correlated with NGAL levels. Further research is warranted regarding urine catalytic iron and its relationship to AKI. Our findings suggest the possibility of iron chelation as an approach to prevent or lessen cardiac surgery-associated AKI.

\section{Acknowledgements}

We thank all nursing and technical staff at Providence Hospitals and Medical Centers and laboratorians at the University of Arkansas for Medical Sciences for their kindness to co-ordinate and assist for serial specimen collection and measurement.

\section{Disclosure Statement}

There are no competing interests. 


\section{CardioRenal Medicine}

\begin{tabular}{l|l}
\hline Cardiorenal Med 2013;3:7-16 \\
\hline DOI: $\underline{10.1159 / 000346815}$ & $\begin{array}{l}\text { @ 2013 S. Karger AG, Basel } \\
\text { www.karger.com/crm }\end{array}$ \\
\hline
\end{tabular}

Akrawinthawong et al.: Urine Catalytic Iron and Neutrophil Gelatinase-Associated Lipocalin as Companion Early Markers of Acute Kidney Injury after Cardiac Surgery

\section{References}

1 Chertow GM, Burdick E, Honour M, Bonventre JV, Bates DW: Acute kidney injury, mortality, length of stay, and costs in hospitalized patients. J Am Soc Nephrol 2005;16:3365-3370.

- 2 Uchino S, Kellum JA, Bellomo R, Doig GS, Morimatsu H, Morgera S, Schetz M, Tan I, Bouman C, Macedo E, Gibney N, Tolwani A, Ronco C: Acute renal failure in critically ill patients: a multinational, multicenter study. JAMA 2005;294:813-818.

3 Haase M, Bellomo R, Devarajan P, Schlattmann P, Haase-Fielitz A: Accuracy of neutrophil gelatinase-associated lipocalin (NGAL) in diagnosis and prognosis in acute kidney injury: a systematic review and meta-analysis. Am J Kidney Dis 2009;54:1012-1024.

4 Mishra J, Ma Q, Prada A, Mitsnefes M, Zahedi K, Yang J, Barasch J, Devarajan P: Identification of neutrophil gelatinase-associated lipocalin as a novel early urinary biomarker for ischemic renal injury. J Am Soc Nephrol 2003;14:2534-2543.

5 Ichimura T, Bonventre JV, Bailly V, Wei H, Hession CA, Cate RL, Sanicola M: Kidney injury molecule-1 (KIM-1), a putative epithelial cell adhesion molecule containing a novel immunoglobulin domain, is up-regulated in renal cells after injury. J Biol Chem 1998;273:4135-4142.

6 Schinstock CA, Semret MH, Wagner SJ, Borland TM, Bryant SC, Kashani KB, Larson TS, Lieske JC: Urinalysis is more specific and urinary neutrophil gelatinase-associated lipocalin is more sensitive for early detection of acute kidney injury. Nephrol Dial Transplant 2012, E-pub ahead of print.

7 Jeong TD, Kim S, Lee W, Song GW, Kim YK, Chun S, Lee SG, Min WK: Neutrophil gelatinase-associated lipocalin as an early biomarker of acute kidney injury in liver transplantation. Clin Transplant 2012, DOI: 10.1111/j.1399-0012.2012.01610.x, E-pub ahead of print.

- 8 Koyner JL, Garg AX, Coca SG, Sint K, Thiessen-Philbrook H, Patel UD, Shlipak MG, Parikh CR: Biomarkers predict progression of acute kidney injury after cardiac surgery. J Am Soc Nephrol 2012;23:905-914.

9 McCullough PA, El-Ghoroury M, Yamasaki H: Early detection of acute kidney injury with neutrophil gelatinaseassociated lipocalin. J Am Coll Cardiol 2011;57:1762-1764.

$\checkmark 10$ Mcllroy DR, Wagener G, Lee HT: Neutrophil gelatinase-associated lipocalin and acute kidney injury after cardiac surgery: the effect of baseline renal function on diagnostic performance. Clin J Am Soc Nephrol 2010; 5:211-219.

11 Bolignano D, Lacquaniti A, Coppolino G, Donato V, Campo S, Fazio MR, Nicocia G, Buemi M: Neutrophil gelatinase-associated lipocalin (NGAL) and progression of chronic kidney disease. Clin J Am Soc Nephrol 2009;4: 337-344.

12 Schmidt-Ott KM, Mori K, Li JY, Kalandadze A, Cohen DJ, Devarajan P, Barasch J: Dual action of neutrophil gelatinase-associated lipocalin. J Am Soc Nephrol 2007;18:407-413.

-13 Shah SV, Rajapurkar MM, Baliga R: The role of catalytic iron in acute kidney injury. Clin J Am Soc Nephrol 2011; 6:2329-2331.

14 Ho J, Reslerova M, Gali B, Gao A, Bestland J, Rush DN, Nickerson PW, Rigatto C: Urinary hepcidin-25 and risk of acute kidney injury following cardiopulmonary bypass. Clin J Am Soc Nephrol 2011;6:2340-2346.

15 Haase-Fielitz A, Mertens PR, Plass M, Kuppe H, Hetzer R, Westerman M, Ostland V, Prowle JR, Bellomo R, Haase M: Urine hepcidin has additive value in ruling out cardiopulmonary bypass-associated acute kidney injury: an observational cohort study. Crit Care 2011;15:R186.

16 Yang J, Mori K, Li JY, Barasch J: Iron, lipocalin, and kidney epithelia. Am J Physiol Renal Physiol 2003;285:F9F18.

17 Loef BG, Epema AH, Navis G, Ebels T, van Oeveren W, Henning RH: Off-pump coronary revascularization attenuates transient renal damage compared with on-pump coronary revascularization. Chest 2002;121:11901194.

-18 Hirayama T, Herlitz H, Jonsson 0, Roberts D: Deformability and electrolyte changes of erythrocytes in connection with open heart surgery. Scand J Thorac Cardiovasc Surg 1986;20:253-259.

19 McCullough PA, Williams FJ, Stivers DN, Cannon L, Dixon S, Alexander P, Runyan D, David S: Neutrophil gelatinase-associated lipocalin: a novel marker of contrast nephropathy risk. Am J Nephrol 2012;35:509-514.

20 Haase M, Bellomo R, Haase-Fielitz A: Novel biomarkers, oxidative stress, and the role of labile iron toxicity in cardiopulmonary bypass-associated acute kidney injury. J Am Coll Cardiol 2010;55:2024-2033.

21 Hamada Y, Fukagawa M: Is hepcidin the star player in iron metabolism in chronic kidney disease? Kidney Int 2009;75:873-874.

22 Kulaksiz H, Theilig F, Bachmann S, Gehrke SG, Rost D, Janetzko A, Cetin Y, Stremmel W: The iron-regulatory peptide hormone hepcidin: expression and cellular localization in the mammalian kidney. J Endocrinol 2005; 184:361-370.

23 Larsson J, Allhorn M, Kerstrom B: The lipocalin alpha(1)-microglobulin binds heme in different species. Arch Biochem Biophys 2004;432:196-204.

24 Bernard AM, Vyskocil AA, Mahieu P, Lauwerys RR: Assessment of urinary retinol-binding protein as an index of proximal tubular injury. Clin Chem 1987;33:775-779.

25 Portilla D, Dent C, Sugaya T, Nagothu KK, Kundi I, Moore P, Noiri E, Devarajan P: Liver fatty acid-binding protein as a biomarker of acute kidney injury after cardiac surgery. Kidney Int 2008;73:465-472.

26 Bellomo R, Auriemma S, Fabbri A, D’Onofrio A, Katz N, McCullough PA, Ricci Z, Shaw A, Ronco C: The pathophysiology of cardiac surgery-associated acute kidney injury (CSA-AKI). Int J Artif Organs 2008;31:166-178. 


\section{CardioRenal Medicine}

\begin{tabular}{l|l}
\hline Cardiorenal Med 2013;3:7-16 \\
\hline DOI: $\underline{10.1159 / 000346815}$ & $\begin{array}{l}\text { @ 2013 S. Karger AG, Basel } \\
\text { www.karger.com/crm }\end{array}$ \\
\hline
\end{tabular}

Akrawinthawong et al.: Urine Catalytic Iron and Neutrophil Gelatinase-Associated Lipocalin as Companion Early Markers of Acute Kidney Injury after Cardiac Surgery

27 Menasche P: The systemic factor: the comparative roles of cardiopulmonary bypass and off-pump surgery in the genesis of patient injury during and following cardiac surgery. Ann Thorac Surg 2001;72:S2260-S2265; discussion S2265-S2266, S2267-S2270.

28 Gueret G, Lion F, Guriec N, Arvieux J, Dovergne A, Guennegan C, Bezon E, Baron R, Carre JL, Arvieux C: Acute renal dysfunction after cardiac surgery with cardiopulmonary bypass is associated with plasmatic IL6 increase. Cytokine 2009; 45:92-98.

29 Vermeulen Windsant IC, Snoeijs MG, Hanssen SJ, Altintas S, Heijmans JH, Koeppel TA, Schurink GW, Buurman WA, Jacobs MJ: Hemolysis is associated with acute kidney injury during major aortic surgery. Kidney Int 2010; 77:913-920.

-30 Takami Y, Makinouchi K, Nakazawa T, Glueck J, Benkowski R, Nose Y: Effect of surface roughness on hemolysis in a pivot bearing supported Gyro centrifugal pump (C1E3). Artif Organs 1996;20:1155-1161.

-31 Kanamori Y, Tanabe H, Shimono T, Tani K, Yada I, Yuasa H, Kusagawa M: The effects of administration of haptoglobin for hemolysis by extracorporeal circulation [in Japanese]. Rinsho Kyobu Geka 1989;9:463-467.

-32 Donadee C, Raat NJ, Kanias T, Tejero J, Lee JS, Kelley EE, Zhao X, Liu C, Reynolds H, Azarov I, Frizzell S, Meyer EM, Donnenberg AD, Qu L, Triulzi D, Kim-Shapiro DB, Gladwin MT: Nitric oxide scavenging by red blood cell microparticles and cell-free hemoglobin as a mechanism for the red cell storage lesion. Circulation 2011;124: 465-476.

33 Gutteridge JM: Iron promoters of the Fenton reaction and lipid peroxidation can be released from haemoglobin by peroxides. FEBS Lett 1986;201:291-295.

-34 Zager RA, Foerder CA: Effects of inorganic iron and myoglobin on in vitro proximal tubular lipid peroxidation and cytotoxicity. J Clin Invest 1992;89:989-995.

-35 Zager RA, Schimpf BA, Bredl CR, Gmur DJ: Inorganic iron effects on in vitro hypoxic proximal renal tubular cell injury. J Clin Invest 1993;91:702-708.

-36 Pardo-Mindan FJ, Diez J, Esparza N, Robledo C: Renal siderosis in patients with heart-valve prostheses: clinical implications. Nephrol Dial Transplant 1990;5:847-850.

37 Landing BH, Gonick HC, Nadorra RL, Hyman CB, Wells TR, Villarreal-Engelhardt G, Mersch J, Agness CL: Renal lesions and clinical findings in thalassemia major and other chronic anemias with hemosiderosis. Pediatr Pathol 1989;9:479-500.

-38 Anderson BF, Baker HM, Norris GE, Rice DW, Baker EN: Structure of human lactoferrin: crystallographic structure analysis and refinement at 2.8 A resolution. J Mol Biol 1989;209:711-734.

-39 Hershko C, Graham G, Bates GW, Rachmilewitz EA: Non-specific serum iron in thalassaemia: an abnormal serum iron fraction of potential toxicity. Br J Haematol 1978;40:255-263.

40 Ponka P: Cellular iron metabolism. Kidney Int Suppl 1999;69:S2-S11.

41 Haase M, Bellomo R, Story D, Letis A, Klemz K, Matalanis G, Seevanayagam S, Dragun D, Seeliger E, Mertens PR, Haase-Fielitz A: Effect of mean arterial pressure, haemoglobin and blood transfusion during cardiopulmonary bypass on post-operative acute kidney injury. Nephrol Dial Transplant 2012;27:153-160.

42 Doi K, Suzuki Y, Nakao A, Fujita T, Noiri E: Radical scavenger edaravone developed for clinical use ameliorates ischemia/reperfusion injury in rat kidney. Kidney Int 2004;65:1714-1723.

43 Takebayashi S, Jimi S, Segawa M, Takaki A: Mitochondrial DNA deletion of proximal tubules is the result of itaiitai disease. Clin Exp Nephrol 2003;7:18-26.

44 Prowle JR, Ostland V, Calzavacca P, Licari E, Ligabo EV, Echeverri JE, Bagshaw SM, Haase-Fielitz A, Haase M, Westerman M, Bellomo R: Greater increase in urinary hepcidin predicts protection from acute kidney injury after cardiopulmonary bypass. Nephrol Dial Transplant 2012;27:595-602.

45 Rajapurkar MM, Shah SV, Lele SS, Hegde UN, Lensing SY, Gohel K, Mukhopadhyay B, Gang S, Eigenbrodt ML: -Association of catalytic iron with cardiovascular disease. Am J Cardiol 2012;109:438-442. 